\title{
Alleviation of Polyatomic Ion Interferences for Determination of Chlorine Isotope Ratios by Inductively Coupled Plasma Mass Spectrometry
}

\author{
F. G. Smith and R. S. Houk
}

Ames Laboratory-U.S. Department of Energy, Department of Chemistry, Iowa State University, Ames, Iowa, USA

A simple variation in sample preparation and introduction allows the measurement of chlorine isotope ratios by inductively coupled plasma mass spectrometry (ICP/MS). Dissolution of the sample in $\mathrm{D}_{2} \mathrm{O}$ rather than $\mathrm{H}_{2} \mathrm{O}$ attenuates the major polyatomic ion ${ }^{36} \mathrm{ArH}^{+}$and frees $\mathrm{m} / \mathrm{z} 37$ for determination of ${ }^{37} \mathrm{Cl}^{+}$. The isotope ratio ${ }^{35} \mathrm{Cl} /{ }^{37} \mathrm{Cl}$ in a $50 \mathrm{mg} / \mathrm{L}$ solution of $\mathrm{Cl}$ as $\mathrm{LiCl}$ is determined with a relative standard deviation of $0.21 \%$. Sample memory is low, as the ${ }^{35} \mathrm{Cl}$ signal decays to less than $1 \%$ of its original value after $\sim 2 \mathrm{~min}$ of cleanout with $\mathrm{D}_{2} \mathrm{O}$. The detection limit for $\mathrm{Cl}$ using this procedure is approximately $20 \mu \mathrm{g} / \mathrm{L}$. (I $A m$ Soc Mass Spectrom 1990, 1, 284-287)

I nductively coupled plasma mass spectrometry (ICP/MS) is a fast method for the determination of elemental concentrations and stable isotope ratios [1-6]. Determination of isotope ratios for the intracellular electrolytes magnesium, potassium, and chlorine is important for monitoring physiological function [7-10]. The determination of $\mathrm{Mg}$ is straightforward [11], but $\mathrm{K}$ requires major modification of plasma operating conditions [12] or the use of a completely different plasma [13] or flame [14]. Determination of $\mathrm{Cl}$ is difficult for two reasons. First, the degree of ionization of $\mathrm{Cl}$ is only $\sim 0.1-1 \%$ in the plasma [15], so the sensitivity is lower than for other elements. Second, the major polyatomic ion ${ }^{36} \mathrm{ArH}^{+}$overlaps with ${ }^{37} \mathrm{Cl}^{+}$. Chlorine can be detected as the negative ion $\mathrm{Cl}^{-}$by ICP/MS, but the high background degrades detection limits [16, 17]. A helium-supported ICP was studied with ICP/MS for the detection of $\mathrm{Cl}$ in gaseous organic samples [18]. However, the introduction of water often destabilizes helium plasmas and causes poor or erratic performance. Recently, a helium microwave-induced plasma (MIP) coupled to a mass spectrometer demonstrated a $\mathrm{Cl}$ detection limit of $39 \mu \mathrm{g} / \mathrm{L}$ for aqueous samples, but an isotope ratio was not reported [19]. Bromine is more readily measured and has been proposed as a substitute for $\mathrm{Cl}$ in physiological experiments [20], but a direct determination of $\mathrm{Cl}$ is also desirable.

This paper describes a simple procedure that allows the measurement of $\mathrm{Cl}$ isotope ratios by using $\mathrm{Cl}^{+}$. The sample is dissolved in $99.9 \% \mathrm{D}_{2} \mathrm{O}$, so little nebu-

Address reprint requegts to R. S. Houk, Department of Chemistry, Iowa State University, Ames, IA 50011. lized water is injected into the plasma. Because most of the hydrogen comes from the injected water, the problematic polyatomic ion is now ${ }^{36} \mathrm{ArD}^{+}$at $m / z 38$. The ${ }^{36} \mathrm{ArH}^{+}$background decreases, which facilitates determination of ${ }^{37} \mathrm{Cl}$.

\section{Experimental}

\section{Instrumentation}

The Sciex ELAN Model 250 (Perkin-Elmer, Thornhill, Ontario) was used. The cryopump and mass spectrometer electronics were cooled with an HX-150 recirculating water chiller (Neslab Instruments, Portsmouth, $\mathrm{NH}$ ). The water temperature was set at $10^{\circ} \mathrm{C}$. The nebulizer gas flow rate was regulated by a mass flow controller from Matheson Scientific (East Rutherford, NJ). Samples were introduced to the nebulizer at a rate of $0.5 \mathrm{~mL} / \mathrm{min}$ by a Rainin minipuls 2 peristaltic pump (Rainin Instrument Co., Woburn, MA). The continuous flow ultrasonic nebulizer was operated at a forward power of 40-45 W [21, 22]. The wet aerosol was desolvated with a heating chamber $\left(200^{\circ} \mathrm{C}\right)$ and a condenser $\left(0^{\circ} \mathrm{C}\right)$ [22] and was transported to the plasma through tygon tubing ( $\sim 1 \mathrm{~m}$ long).

\section{Chemicals and Sample Preparation}

The $99.9 \% \mathrm{D}_{2} \mathrm{O}$ was obtained from Cambridge Isotope Laboratories (Woburn, MA). Lithium chloride from Fisher Scientific (Fair Lawn, NJ) was used as the source of $\mathrm{Cl}$. This compound was chosen because the light $\mathrm{Li}^{+}$ion should cause less suppression of $\mathrm{Cl}^{+}$signal than a heavier counterion like $\mathrm{K}^{+}$or $\mathrm{Na}^{+}[23,24]$. High purity deionized water (resistance $\sim 18 \mathrm{M} \Omega$ ) was 
Table 1. Operating conditions

\begin{tabular}{|c|c|}
\hline ICP torch & $\begin{array}{l}\text { Ames Laboratory design [25]; } \\
\text { outer tube extended } 30 \\
\text { mm from inner tubes }\end{array}$ \\
\hline Forward power & $1.25 \mathrm{~kW}$ \\
\hline $\begin{array}{l}\text { Argon flow rates } \\
\text { Outer gas } \\
\text { Auxiliary gas } \\
\text { Aerosol gas }\end{array}$ & $\begin{array}{l}13 \mathrm{~L} / \mathrm{min} \\
0.2 \mathrm{~L} / \mathrm{min} \\
1.59 \mathrm{~L} / \mathrm{min}\end{array}$ \\
\hline Sampling position & $\begin{array}{l}17 \mathrm{~mm} \text { from load coil, on } \\
\text { center }\end{array}$ \\
\hline Sampler & Nickel, $1.1 \mathrm{~mm}$ diam orifice \\
\hline Skimmer & Nickel, $0.9 \mathrm{~mm}$ diam orifice \\
\hline $\begin{array}{l}\text { Ion lens settings } \\
\text { Bessel box barrel } \\
\text { Bessel box plate } \\
\text { Einzel } 1 \text { and } 3 \\
\text { Einzel } 2 \\
\text { Bessel box stop }\end{array}$ & $\begin{array}{l}+5.4 \mathrm{~V} \\
-11.0 \mathrm{~V} \\
-19.8 \mathrm{~V} \\
-130 \mathrm{~V} \\
-4.9 \mathrm{~V}\end{array}$ \\
\hline Electron multiplier voltage & $-3200 \mathrm{~V}$ \\
\hline $\begin{array}{l}\text { Operating pressures } \\
\text { Interface } \\
\text { Quadrupole chamber }\end{array}$ & $\begin{array}{l}1 \text { torr } \\
3 \times 10^{-5} \text { torr }\end{array}$ \\
\hline Data acquisition & $\begin{array}{l}\text { Low resolution settirig; } \\
\text { measurements per peak } \\
\text { spaced } 0.1 \mathrm{~m} / \mathrm{z} \text { unit about } \\
\text { peak top }\end{array}$ \\
\hline $\begin{array}{l}{ }^{35} \mathrm{Cl} /{ }^{37} \mathrm{Cl} \text { ratio and back- } \\
\text { ground measurements }\end{array}$ & $\begin{array}{l}\text { Multielement monitoring mode, } \\
\text { three measurements per } \\
\text { peak, dwell time } 1 \mathrm{~ms} \text { at } \\
\text { each position, total } \\
\text { measurement time } 1.0 \mathrm{~s}\end{array}$ \\
\hline Cleanout study & $\begin{array}{l}\text { Multielement monitoring mode, } \\
\text { three measurements per } \\
\text { peak, dwell time } 20 \mathrm{~ms} \text {, } \\
\text { total measurement time } 0.5 \mathrm{~s}\end{array}$ \\
\hline Spectra & $\begin{array}{l}\text { Sequential monitoring mode, } \\
10 \text { measurements per peak, } \\
\text { total measurement time } 1.0 \mathrm{~s}\end{array}$ \\
\hline
\end{tabular}

obtained from a Barnstead Nanopure-II system (Barnstead Co., Newton, MA). A $50 \mathrm{mg} / \mathrm{L}$ chlorine solution was prepared in $\mathrm{D}_{2} \mathrm{O}$. The $\mathrm{LiCl}$ used was dried in an oven at $250^{\circ} \mathrm{C}$ and stored in a desiccator. An accurately weighed amount of $\mathrm{LiCl}$ was then dissolved directly in $50.0 \mathrm{~mL}$ of $\mathrm{D}_{2} \mathrm{O}$.

\section{Instrumental Conditions}

General instrumental and sampling conditions are given in Table 1. Isotope ratios were measured in a peak-hopping mode, and spectra were obtained by scanning, as described in Table 1 . Before each experiment, the sample introduction system was kept as free from water as possible in the following ways. The spray chamber of the nebulizer and the desolvation system were dried with a heat gun. In addition, the waste U-tube leading from the spray chamber and the condenser was filled with $\mathrm{D}_{2} \mathrm{O}$. Operating conditions for the instrument were adjusted to maximize the signal from ${ }^{36} \mathrm{Ar}^{+}$while nebulizing $\mathrm{D}_{2} \mathrm{O}$. This procedure was employed because nebulization of aqueous standard solutions during optimization of operating condi- tions would have contaminated the sample introduction device with water.

\section{Results and Discussion}

\section{Mass Spectra}

The background mass spectrum obtained during nebulization of $\mathrm{D}_{2} \mathrm{O}$ is shown in Figure 1. The major background ions in the given mass range are ${ }^{16} \mathrm{O}_{2}{ }^{+},{ }^{36} \mathrm{Ar}^{+}$ and both ${ }^{38} \mathrm{Ar}^{+}$and ${ }^{36} \mathrm{ArD}^{+}$at $m / z$ 38. The injection of $\mathrm{D}_{2} \mathrm{O}$ yields a peak at $m / z 34$ that is from $\mathrm{DO}_{2}{ }^{+}$.

The magnitude of the background at $\mathrm{m} / \mathrm{z} 35$ and $m / z 37$ is shown in Table 2 . Most of the background at $m / z 37$ is probably from residual ${ }^{36} \mathrm{ArH}^{+}$. Hydrogen, water, or hydrocarbons in the argon and water impurity in the $\mathrm{D}_{2} \mathrm{O}$ are the likely sources of hydrogen. Numerous polyatomic ions contribute to the background at $m / z$ 35; these are probably ${ }^{16} \mathrm{O}^{17} \mathrm{OD}^{+},{ }^{17} \mathrm{O}^{17} \mathrm{OH}^{+}$, ${ }^{18} \mathrm{O}^{16} \mathrm{OH}^{+}$, and ${ }^{17} \mathrm{O}^{18} \mathrm{O}^{+}$.

A spectrum obtained during nebulization of the $\mathrm{LiCl}$ sample $\left(50 \mathrm{mg} / \mathrm{L}\right.$ in $\mathrm{D}_{2} \mathrm{O}$ ) is shown in Figure 2. Both $\mathrm{Cl}$ isotopes $(\mathrm{m} / \mathrm{z} 35$ and 37$)$ were clearly observed. The background peaks at $m / z 36$ and $m / z 38$ are suppressed by approximately $40 \%$ relative to the count rates seen from the $\mathrm{D}_{2} \mathrm{O}$ blank solution. The $\mathrm{DO}_{2}{ }^{+}$ peak at $m / z 34$ is of about the same intensity in Figures 1 and 2 .

Deionized water was then introduced into the ICP. The count rate at $m / z 37$ was monitored in the multielement mode until a steady value was reached. The nebulizer and desolvation system became saturated with water in approximately $30 \mathrm{~min}$. The background mass spectrum from deionized water was then obtained (Figure 3). A substantial peak from ${ }^{36} \mathrm{ArH}^{+}$is readily apparent at $m / z 37$. In addition, the $\mathrm{DO}_{2}{ }^{+}$peak at $m / z 34$ has been replaced by $\mathrm{HO}_{2}{ }^{+}$at $m / z$ 33. The count rates given in Table 2 show that injection of $\mathrm{D}_{2} \mathrm{O}$ rather than $\mathrm{H}_{2} \mathrm{O}$ reduces the background at $m / z 37$ by almost a factor of 10 . The background at $m / z 35$ is still modest when $\mathrm{D}_{2} \mathrm{O}$ is nebulized; an increase of a factor of 2 is indicated. Thus, $\mathrm{m} / \mathrm{z} 35$ remains fairly clear.

\section{Isotope Ratio Measurements}

Isotope ratio and sensitivity data for the $50 \mathrm{mg} / \mathrm{L}$ solution of $\mathrm{Cl}$ in $\mathrm{D}_{2} \mathrm{O}$ are shown in Table 3 . These data

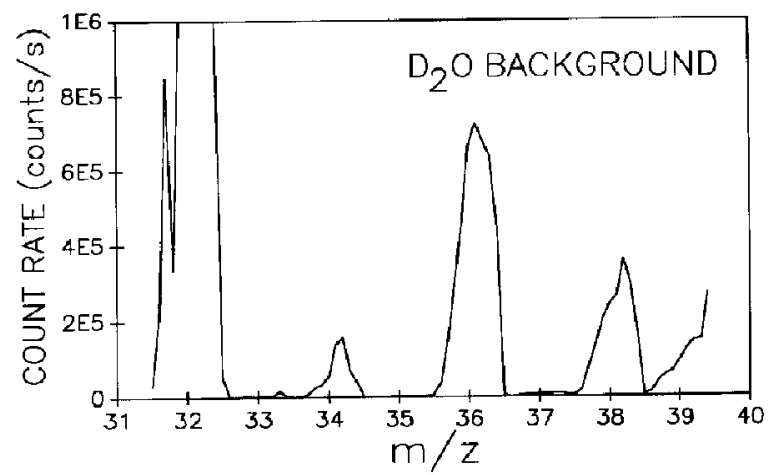

Figure 1. Background spectrum of $99.9 \% \mathrm{D}_{2} \mathrm{O}$. 
Table 2. Background count rates

\begin{tabular}{|c|c|c|c|c|}
\hline \multirow[b]{4}{*}{$\begin{array}{l}\text { Blank } \\
\text { solution }\end{array}$} & \multicolumn{4}{|c|}{ Background Count Rates } \\
\hline & \multicolumn{2}{|c|}{$m / z 35$} & \multicolumn{2}{|c|}{$m / 237$} \\
\hline & \multicolumn{2}{|c|}{ Mean } & \multicolumn{2}{|c|}{ Mean } \\
\hline & $\{\text { counts/s }\}^{a}$ & $\begin{array}{l}\text { RSD } \\
(\%)^{\circ}\end{array}$ & $(\text { counts } / \mathrm{s})^{\mathrm{a}}$ & $\begin{array}{l}\text { RSD } \\
(\%)^{\circ}\end{array}$ \\
\hline $\mathrm{D}_{2} \mathrm{O}$ & 3,900 & 2.6 & 5,900 & 2.8 \\
\hline $\mathrm{H}_{2} \mathrm{O}$ & 2,100 & 2.3 & 57,300 & 3.4 \\
\hline
\end{tabular}

a Measurement time was $1.0 \mathrm{~s}$

- Relative standard deviation of 20 measurements.

were obtained by using a very short dwell time ( $1 \mathrm{~ms}$ ) so more measurements could be taken in the 1.0-s measurement time. Rapid measurements may help average out fluctuations in the intensity of the ion beam [26, 27]. However, the acquisition of 20 ratio measurements takes approximately $12 \mathrm{~min}$, partly because of the 4ms computer overhead between hops. Nonetheless, if samples containing $\mathrm{Cl}$ are sufficiently concentrated (10-100 mg/L), then the $\mathrm{Cl}^{+}$signal is high enough for the remaining background to be unimportant.

In this case, the precision for the ratio ${ }^{35} \mathrm{Cl} /{ }^{37} \mathrm{Cl}$ was $0.21 \%$ RSD, which was comparable to that expected from counting statistics based on the total counts accumulated for each peak. Similar precision was obtained when the experiment was repeated on a different day. The close agreement between the experimental precision and that expected from counting statistics is unusual. For ion count rates in the range of $10^{5}-10^{6}$ counts/s, the experimental precision for isotope ratios measured with this particular instrument (and others like it) is generally worse than the precision expected from counting statistics by a factor of $2-4[5,6,10,12$, $27,28,30$ ]. The fast peak hopping (dwell time $1 \mathrm{~ms}$ ) employed in the present work may help improve precision, as indicated in other, preliminary measurements with silver and zinc [27]. The RSD in the isotope ratio $(0.21 \%)$ was much better than the RSD of $1.8 \%$ for the count rates for either ${ }^{35} \mathrm{Cl}^{+}$or ${ }^{37} \mathrm{Cl}^{+}$. These latter RSDs are typical of the short-term precision in the signal achievable by present ICP/MS devices at these count rates. They are well above the counting statistics values of $0.1-0.2 \%$ (not shown in Table 3).

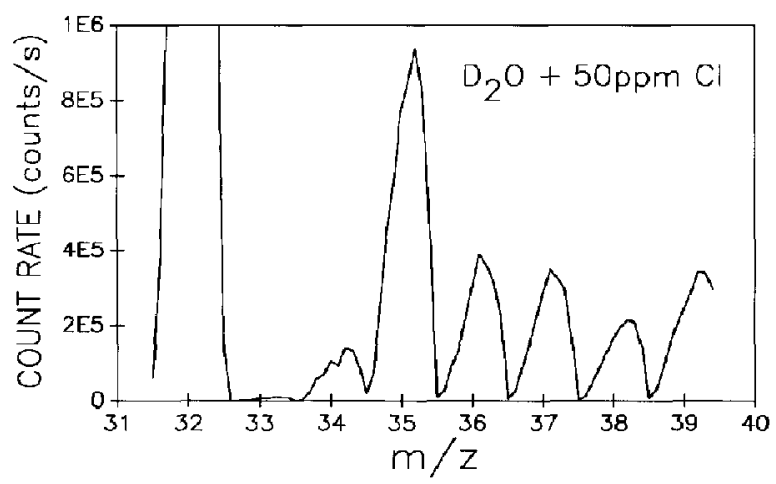

Figure 2. Spectrum of $50 \mathrm{mg} / \mathrm{L} \mathrm{Cl}$ (as $\mathrm{LiCl}$ ) in $\mathrm{D}_{2} \mathrm{O}$.
Table 3. Chlorine isotope ratio measurements

\begin{tabular}{|c|c|c|c|c|c|c|}
\hline \multicolumn{2}{|c|}{$\begin{array}{l}{ }^{35} \mathrm{Cl} \text { count rate } \\
\text { [counts/s) }\end{array}$} & \multicolumn{2}{|c|}{$\begin{array}{c}{ }^{37} \mathrm{Cl} \text { count rate } \\
\text { (counts/s) }\end{array}$} & \multicolumn{2}{|c|}{$\begin{array}{l}\text { Determined } \\
{ }^{35} \mathrm{Cl}^{37} \mathrm{Cl}\end{array}$} & \multirow{2}{*}{$\begin{array}{l}\text { RSD (\%) for } \\
{ }^{35} \mathrm{Cl} /{ }^{37} \mathrm{Cl} \\
\text { counting } \\
\text { stats }\end{array}$} \\
\hline Mean & $\begin{array}{l}\text { RSD } \\
(\%)\end{array}$ & Mean & $\begin{array}{l}\text { RSD } \\
(\%)\end{array}$ & Mean & $\begin{array}{l}\text { RSD } \\
(\%)\end{array}$ & \\
\hline 793,000 & 1.8 & 277,200 & 1.8 & 2.861 & 0.21 & 0.22 \\
\hline
\end{tabular}

Mean and ASD of 20 measurements are reported. Measurement time was 1.0 s. Count rates are corrected for $D_{2} \mathrm{O}$ background. Accapted natural ratio $=3.127[29]$.

The determined value for the ${ }^{35} \mathrm{Cl}^{37} \mathrm{Cl}$ ratio in Table 3 is about $9 \%$ below the accepted natural abundance ratio. Mass bias cffects for other isotopes $2 \mathrm{~m} / \mathrm{z}$ units apart can cause determined ratios to deviate from accepted values by $2-10 \%[2,4,30,31]$. The somewhat low value for the ${ }^{35} \mathrm{Cl}^{+} / \beta^{37} \mathrm{Cl}^{+}$ratio may also have been caused by loss of gain in the detector during measurement of ${ }^{35} \mathrm{Cl}^{+}$, which was quite possible at count rates approaching $10^{6}$ count/s [32, 33]. Plasma operating conditions and ion lens voltages are known to influence isotope ratio values [12], but no experiments with these parameters were performed in this study because of the limited amount of $\mathrm{D}_{2} \mathrm{O}$ available.

The detection limit (i.e., the solution concentration necessary to yield a net signal equivalent to three times the standard deviation of the background) was $20 \mu \mathrm{g} / \mathrm{L}$ for $\mathrm{Cl}$ using ${ }^{35} \mathrm{Cl}^{+}$. This value is comparable to other detection limits reported for $\mathrm{Cl}$ as $\mathrm{Cl}^{-}$from an argon ICP $[16,17]$ or $\mathrm{Cl}^{+}$from a helium MIP [19]. Typically, we observe ion count rates of $\sim 10^{6}$ counts $/(\mathrm{s} \cdot \mathrm{mg} \cdot \mathrm{L})$ for a metal ion of medium mass $(m / z \sim 23-60)$ that would be expected to be nearly $100 \%$ ionized in the ICP. Comparison of this value to the ${ }^{35} \mathrm{Cl}^{+}$count rate in Table 3 shows that $\mathrm{Cl}$ is of the order of $1 \%$ ionized, as expected [15].

\section{Sample Cleanout}

Figure 4 shows a cleanout curve for the $50-\mathrm{mg} / \mathrm{L}$ sample in $D_{2} \mathrm{O}$. The uriginal signal for ${ }^{35} \mathrm{Cl}^{+}(\sim 800,000$ counts/s) decays to approximately 4500 counts/s after $\sim 2 \mathrm{~min}$. This level corresponds to about $0.5 \%$ of the original signal and is only several hundred counts per second above the $\mathrm{D}_{2} \mathrm{O}$ background at $m / z 35$ in Table 2. Elements such as osmium, boron, and mercury that have forms that are volatile at the temperature of the heating chamber $\left(200^{\circ} \mathrm{C}\right)$ can suffer from long memory or loss with the desolvation system employed [22], but apparently this was not a problem for $\mathrm{Cl}$ in the present work.

This rapid cleanout of ${ }^{35} \mathrm{Cl}^{+}$is necessary owing to the expense of $\mathrm{D}_{2} \mathrm{O}$, and two simple measures greatly reduce sample memory. A fresh length of tygon tubing was installed between the desolvator and the plasma, and the nebulizer spray chamber was soaked in concentrated $\mathrm{H}_{2} \mathrm{SO}_{4}$ for $24 \mathrm{~h}$. The former provided an aerosol conduit free from long-term sample memory, whereas the latter facilitated smooth drainage of condensed droplets from the walls of the spray chamber. 


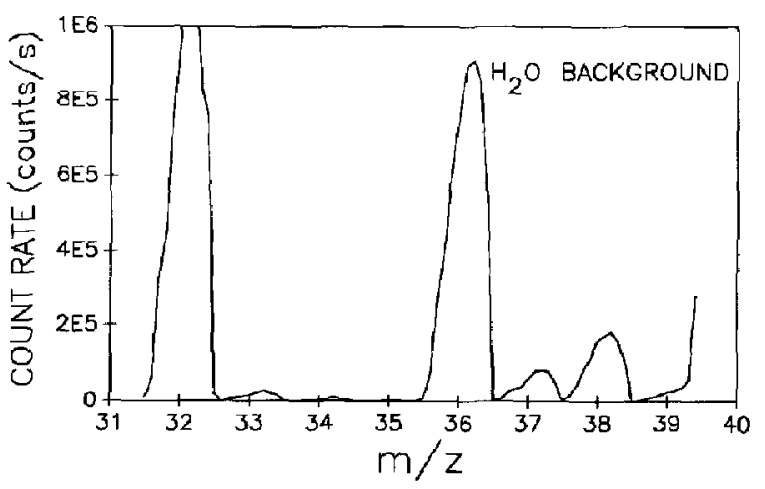

Figure 3. Spectrum of deionized $\mathrm{H}_{2} \mathrm{O}$.

\section{Conclusions}

Sample dissolution in $\mathrm{D}_{2} \mathrm{O}$ can significantly reduce the ${ }^{36} \mathrm{ArH}^{+}$interference and allow the measurement of the ${ }^{35} \mathrm{Cl}^{37} \mathrm{Cl}$ ratio. The precision of $0.2 \%$ RSD is at least as good as that obtained in ICP/MS for other elements and approaches the $0.1 \%$ level desirable for widespread application studies [10]. A substantial amount of $\mathrm{Cl}(0.1-1 \mathrm{mg})$ is required, but most biological samples contain high concentrations of this element. For example, the normal $\mathrm{Cl}$ content of human blood is $\sim 100 \mathrm{mmol} / \mathrm{L}$ [34], so a sample volume of only $30 \mu \mathrm{L}$ is necessary to provide $0.1 \mathrm{mg}$ of $\mathrm{Cl}$. As in most present isotope tracer studies with ICP/MS, sample cleanup would likely be desirable to remove the biological matrix (proteins, etc.) and interfering metal ions such as $\mathrm{Na}^{+}$and $\mathrm{K}^{+}[23,24]$. A blood sample could be centrifuged and the resulting serum transferred to a cation-exchange column in the $\mathrm{Li}^{+}$form. The collected solution would be evaporated to dryness and reconstituted in $\mathrm{D}_{2} \mathrm{O}$. Such refinements in sample preparation should lead to a useful protocol for fast measurement of $\mathrm{Cl}$ isotope ratios by ICP/MS.

\section{Acknowledgment}

The Ames Laboratory is operated by lowa State University for the U.S. Department of Energy under contract no. W-740.5-ENG82. This research was supported by the Office of Basic Energy

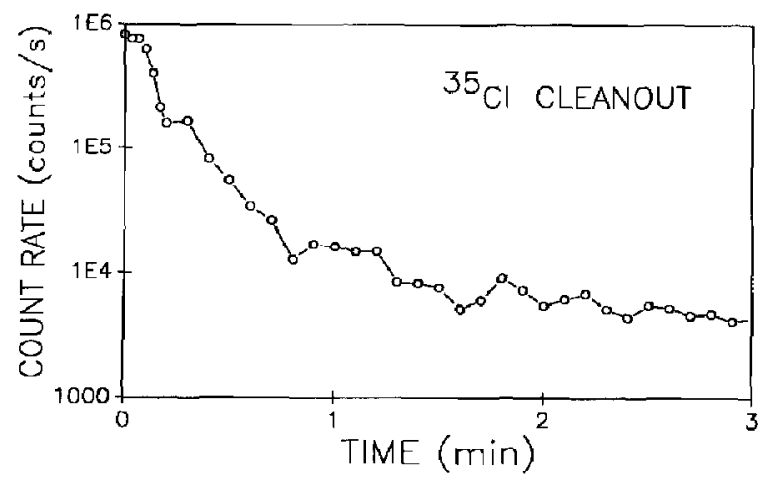

Figure 4. Cleanout curve for ${ }^{35} \mathrm{Cl}^{+}$.
Sciences. The helpful comments of $M$. Janghorbani are gratefully acknowledged.

\section{References}

1. Dean, J. R.; Massey, R.; Ebdon, L. J. Anal. Atomic Spectrom. $1987,2,369$.

2. Russ, G. P. III; Bazan. J. M. Spectrochim. Acta 1987, $42 B_{r} 49$.

3. Longerich, H. P.; Fryer, B. J.; Strong, D. F. Spectrochim Acta 1987, 42B, 39.

4. Ting, B. T. G.; Janghorbani, M. Spectrochim. Acta 1987, 42B, 21.

5. Serfass, R. E,; Thompson, J. J.; Houk, R. S. Anal. Chim. Acta 1986, 188, 73 .

6. Janghorbani, M.; Ting, B. T. G.; Fomon, S. J. Am. J. Hernatol. 1986, 21, 277.

7. Altura, B. M.; Durlach, J.; Seelig, M. S. Magnesitm in Cellulat Processes and Medicine; Karger: New York, 1987.

8. Whang, R. Potassium: Its Biological Significance; CRC Press: Cleveland, 1983.

9. Moore, F. D.; Olesen, K. H.; McMurrey, J. D.; Parker, H. V.; Ball, M. R.; Boyden, C. M. The Body Cell Mass and Its Supporting Environment; W. B. Saunders: Philadelphia, 1963.

10. Janghorbani, M. Personal communication, 1989.

11. Schuette, S.; Vereault, D.; Ting, B. T. G.; Janghorbani, M. Analyst 1988, 113, 1837.

12. Jiang, S.-J.; Houk, R. S.; Stevens, M. A. Anal. Chem. 1988, $60,1217$.

13. Caruso, J. A.; Creed, J. T.; Shen, W. L. Presented at the 16th Annual FACSS Meeting, Chicago, IL, October 1989; paper no. 348 .

14. Taylor, H. E.; Garbarino, J. R. Presented at the 30th Annual Rocky Mountain Conference, Denver, CO, August 1988; par per 175.

15. Houk, R. S. Anal. Chem. 1986, 58, 97A.

16. Fulford, J. E.; Quan, E. S. K. Appl. Spectrosc. 1988, 42, 425.

17. Vickers, G. H.; Wilson, D. A.; Hieftje, G. M. Anal. Chem. 1988, 60, 1808.

18. Montaser, A.; Chan, S. K.; Koppenaal, D. Anal. Chem. 1987, 59,1240 .

19. Creed, J. T.; Davidson, T. M.; Shen, W. L.; Brown, P. G.; Caruso, J. A. Spectrochim. Acta 1989, 44B, 909.

20. Janghorbani, M.; Davis, T. A.; Ting, B. T. G. Analyst 1988, $113,405$.

21. Olson, K. W.; Haas, W. J., Jr.; Fassel, V. A. Anal. Chem. 1977, 49, 632.

22. Bear, B. R.; Fassel, V. A. Spectrochim. Acta 1986, 41B, 1089.

23. 'Jan, S. H.; Horlick, G. J. Anal. Atomic Spectrom. 1987, 2, 283.

24. Gillson, G. R.; Douglas, D. J.; Fulford, J. E.; Halligan, K. W.; Tanner, S, D. Anal. Chem. 1988, 60, 1472.

25. Scott, R. H.; Fassel, V. A.; Kniseley, R. N.; Nixon, D. E. Anal. Chem. 1974, 46, 75.

26. Douglas, D. J. Can. J. Spectrosc. 1989, 34, 38.

27. Houk, R. S.; Smith, F. G.; Wiederin, D. R.; Niu, H. Presented at the 16th Annual FACSS Meeting, Chicago, IL, October 1989; paper 592.

28. Egan, C. B,; Smith, F. G.; Houk, R, S,; Serfass, R. E. Am. I. Clin. Nutrition, 1990.

29. Weast, R. C. (Ed.) CRC Handbook of Chemistry and Physics; CRC Press: Boca Raton, 1985-6; p B-238.

30. Houk, R. S.; Thompson, J. J. Mass Spectrom. Rev. 1988, 7 , 425.

31. Russ, G. P. III; Bazan, J. M.; Date, A. R. Anal. Chem. 1987. 59, 984.

32. Huang, L.-Q.; Jiang, S.-J.; Houk, R. S. Anal. Chem. 1987, 59 , 2316.

33. Kurz, E. A. Am. Lab. March 1979, 11, 67.

34. Benninghoven, J. L., Ed. Saunders Dictionary and Encyclopedia of Laboratory Medicine and Technology; Saunders: Toronto, 1984; p 297. 